\title{
On Dialectics and the Basic Contradiction in Capitalism
}

\author{
Bruno Jossa \\ University of Naples, Naples, Italy \\ Email: bruiossa@unina.it
}

How to cite this paper: Jossa, B. (2017) On Dialectics and the Basic Contradiction in Capitalism. Open Access Library Journal, 4: e2935.

https://doi.org/10.4236/oalib.1102935

Received: May 29, 2017

Accepted: July 11, 2017

Published: July 14, 2017

Copyright $\odot 2017$ by author and Open Access Library Inc.

This work is licensed under the Creative Commons Attribution International License (CC BY 4.0).

http://creativecommons.org/licenses/by/4.0/

\section{(c) (i) Open Access}

\begin{abstract}
The contradiction which is classified as the severest one in most Marxist analyses of society is the plan-market opposition. From this, it follows that the social order that will rise from the ashes of capitalism upon the solution of this contradiction must be a centrally planned and, hence, non-market system. The author emphasizes that, instead, the existence of a different contradiction whose solution is compatible with the assumption that the newly emerging production mode, i.e. socialism, will still be a market economy. In the conclusion, the author mentions a seldom-quoted article that Lenin wrote after his experiments with wartime communism and the Nep and in which he spelt out that "cooperation is socialism".
\end{abstract}

\section{Subject Areas}

Economics, Philosophy

\section{Keywords}

Dialectics, Market Socialism, Capitalistic Contradictions

\section{Introduction}

Apparently, it's a triumph of capitalism; and in actual fact globalisation is only its high water mark. As it brings into focus such a crucial Marxist issue as the full power of markets, it poses the need to "reconcile" Marxism with markets and to draw a clear-cut distinction between socialism and communism.

With respect to this distinction, it is worth specifying right from the start that socialism is a transitional social order which heralds the advent of communism and, above all, that market socialism is the new mode of production which can be expected to take the place of capitalism for such a long period of time as to 
make us cease wondering what will come after it.

Put differently, whereas Marxist is likely to assume that the transition to socialism lies in the nature of things and is bound to become a reality at some point in time, the advent of the production mode known as communism must be deferred in time since it is closely associated with the birth of a new man who has shed part of his egoism and can consequently do without markets.

Today, the prospect of a world without markets is just a utopian dream. As argued by Hodgson ([1] 1999, p. 31), no meaningful long-run economic decentralisation process has ever been proposed "without the equivalent decentralisation of the powers to make contracts, set prices, and exchange products and property rights through markets or other forms of property exchange".

Marx did not distinguish between socialism and communism. The idea that socialism and communism are different social organisation models is widely held, but "for Marx this distinction is non-existent" (see [2] Chattopadhyay, 2010, p. 214).

The reason why this distinction necessitates rethinking Marxist theory is that a system categorised as a market economy can only be analysed to the full if it is brought into line with mainstream economic theory. In other words, this determines that a Marxist setting out to analyse socialism will have to do without Hegelian dialectics, an approach which rejects the non-contradiction principle.

One more point that the necessity of re-defining the distinction between socialism and communism is the key contradiction of capitalism. Indeed, since the contradiction presented as the severest in Marxist theory entails the conclusion that the order to rise from the ashes of capitalism is a centrally planned economy, it is necessary to identify a different contradiction which is compatible with the assumption that the newly emerging production mode, i.e. socialism, will still be a market economy.

This is the working hypothesis of this paper, which

1) expatiates on dialectics in order to identify a form of dialectic which will not be at odds with mainstream economic thought; and

2) subsequently, discusses the key contradiction of capitalism from a vantage point departing from traditional Marxist approaches. ${ }^{1}$

A group of theorists have recently been treading a different path. Specifically, they argue that "the very ontology of knowledge has grown into an antagonistic contradiction with the commodity form" ([6] Rigi, 2013, p. 407), which is tantamount to saying that the ever wider use of computers highlights a different contradiction within capitalism: the contrast between knowledge, which is freely available to anyone by its very nature, and the production of marketable commodities. In their opinion, the production mode of the future, which in fact is already in the making, is peer production (PP), i.e. a system which is characterised by the production of socially owned goods made available to the ${ }^{1}$ This paper elaborates on ideas that were first discussed in The Key Contradiction in Capitalist Systems, published in the Review of Radical Political Economics 2014, vol. 46, no 1. For earlier analyses, see [3] [4] [5] Jossa 2012a, 2012b and 2014b, chap. II. 
community for free use (see [7] Benkler, 2006; [8] Kleiner, 2010; [6] Rigi, 2013).

\section{General Reflections on Dialectics}

"If ever the time comes when such work is again possible-Marx wrote-I should very much like to write two or three sheets making accessible to the common reader the rational aspect of the method which Hegel not only discovered but also mystified" ([9] Marx, 1858, p. 249). Regrettably, he never translated this plan into practice, and this may explain why his dialectical method allows of a variety of different interpretations (see [10] Bhaskar, 1991).

Although he did not deny the unmistakable Hegelian colouring of all Marx's writings, Schumpeter warned that thinking of Hegelism as the keystone of Marxism would be tantamount to debasing the scientific standing of Marx's theoretical edifice. In his opinion, Marx had a taste for "coquetting" with Hegelian phrasing, but did not go any further (see [11] Schumpeter, 1954, p. 9). Authors convinced that Marx gradually ceased his use of dialectics include Rosenthal 1998 [12] and Bidet 1998 ([13], p. 225), while analytical Marxists look upon dialectical reasoning as altogether misleading and, hence, hardly of any more help than formal logic when it comes to flesh out a social theory (see [14] Meyer, 1994, p. 1).

Rodolsky has appropriately argued that ever since the publication of the Grundrisse it has no longer been admissible for an academic to write about Marx as an economist without thoroughly analysing his method and its links with Hegel's. Indeed, he contended, whereas in Capital Hegelian overtones are just perceived in a few footnotes, the Rohentwurfcan be described as a string of references to Hegel, specifically his Logic ([15] Rosdolsky, 1955, p. 8). ${ }^{2}$

Lastly, it is worth noting that the assumed similarities between Marx's and Hegel's dialectical methods have been called into question by a great many authors, with Croce ([19] 1899, pp. 4-9), Hyppolite ([20] 1969, pp. 300-303) and Garaudy ([21] 1969, pp. 312-314) the most prominent among them. ${ }^{3}$

Let me repeat that the main aim of my analysis of dialectics is identifying a contradiction, in capitalism, that Marxists should categorise as the most important of all and that this need is imposed by the fact that the severest contradiction determines what kind of production mode will rise from the ashes of capitalism. The train of reasoning I intend to adopt for my analysis is quite an unusual one. Instead of proceeding, as usual, from the premise to the conclusion, I will take it for granted that the new production mode will be a system of worker-controlled

\footnotetext{
${ }^{2}$ In all probability, the first author to censure Marx for failing to wrest himself free from the influence of Hegel was Conrad Schmidt back in 1865 (see [16] Bernier, 1974, p. 167). Major commentators emphasising the close links between Marx and Hegel include the Italian philosopher Giovanni Gentile ([17] 1974, pp. 31-33 and 44) and, more recently, Rockmore 2005, the author of a masterly analysis concerned with the indissoluble links between Marx and Hegel (see [18] Rockmore, 2005).

${ }^{3}$ In Hegel's own words, dialectics is a "union of opposites" and although the rejection of the non-contradiction principle may make it "nonsensical to the understanding" it must be accepted as "the result of speculative thinking" ([22] Hegel, 1831, p. 14).

On the role of dialectics in Marx's approach, see, also, [23] Dal Pra, 1972; [24] Bidet, 2001; [25] Kincaid, 2001; [26] Fine, 2001; and [27] Bhaskar, 1993.
} 
firms and will raise the question which of the main contradictions identified by Marx in capitalism and which of the dialectical methods he used may support my view that the new mode of production will be a system of democratically managed firms.

The importance of equating the socialist revolution with the transition from capitalism to a system of worker-controlled firms stems from the fact that Marx, refusing to concoct "recipes for the cook-shops of the future", failed to provide a clear outline of the social order he expected to take the place of capitalism. Despite the crucial relevance of the post-capitalistic mode of production for a correct perspective on Marxism, neither Kautsky, who described himself as a socialist all his life, nor any other Marxist critical of the way the Russian revolution was evolving has ever taken the trouble to make it clear how opponents of the Soviet central planning model are to picture to themselves a true socialist order (for Kautsky's silence on this point, see, Geary ([28] 1974, pp. 93-94).

As a matter of fact, the categorisation of democratic firm management as a new mode of production is far from widely accepted. SylosLabini is just one of many academics who reject the assumption that the establishment of a system of producer cooperatives amounts to a revolution, and this is probably the reason why he altogether denies any links between producer cooperative theory and Marxism (see [29] SylosLabini, 2006).

Marx himself did look upon a system of producer cooperatives as a possible new mode of production. In 1864, for instance, he wrote [30]: “But there was in store a still greater victory of the political economy of labour over the political economy of property. We speak of the co-operative movement, especially of the co-operative factories raised by the unassisted efforts of a few bold 'hands'. The value of these great social experiments cannot be over-rated. By deed, instead of by argument, they have shown that production on a large scale, and in accord with the behest of modern science, may be carried on without the existence of a class of masters employing a class of hands; that to bear fruit, the means of labour need not be monopolised as a means of dominion over, and of extortion against, the labouring man himself; and that, like slave labour, like serf labour, hired labour is but a transitory and inferior form, destined to disappear before associated labour plying its toil with a willing had, a ready mind, and a joyous heart". 4

\footnotetext{
${ }^{4}$ The statement, in the Manifesto, that the purpose of revolution was to enable the proletariat to use its political supremacy to "centralise all the instruments of production in the hands of the State" (see [31] Marx, Engels, 1848, p. 312) is of little consequence. Indeed, since Marx did not start fine-tuning his system until 1857, his earlier works can be described as preparatory steps for the full development of his system. Until the time of the Paris Commune, Marx and Engels were persuaded that socialism would be implemented by centralising all powers firmly in the hands of the State. It was the Paris Commune that induced them to retrace their steps and come to conceive of socialism as mainly connoted by fully democratic production processes (see [32] Screpanti, 2007, pp. 145-146). The publication of the Inaugural Address in 1864 marked an end to the period during which they associated communism with the Paris Commune (see [33] Lichtheim, 1965, p. 228). However, it was only in the last years of his life, specifically when he wrote the Critique of the Gotha Programme, that Marx definitively accepted the idea that socialism was centralised planning.
} 


\section{Dialectics as the Analysis of a Totality with Real Oppositions}

In Marxian theory, production, distribution, exchange and consumption are perceived as links of a single chain. Commenting on this point in a youthful work on historical evolution, Lukàcs wrote that Marx, much like the German philosophers and chiefly Hegel, conceived of world history as a homogeneous revolutionary process consistently geared towards the attainment of freedom. The very core of Marx's conception of history, he argued ([34] Lukàcs, 1968, p. $34)$, is the supremacy of totality, i.e. the pre-eminence of the whole over its artificially detached parts.

In this connection, Rovatti ([35] 1973, p. 125) has pointed out that ever since the publication of Lukàcs's History and Class Consciousness, more and more authors have espoused the view that Marx's true aim was to proceed from a fragmented view of the structure of capitalism to an approach capable of highlighting a totality moving consistently forward in a single direction. Similarly, Rusconi 1968 ([36] p. 49) has clarified that Lukàcs rated the "totality perspective" not only as a speculative aid, but as a real and proper "critical method for the interpretation of society" and "a criterion used to make history intelligible", and Negt ([37] 1979, p. 350) has endorsed Lukàcs's view that the totality notion is the key element distinguishing the Marxist from the bourgeois worldview (see, also, [38] Balibar, 1993, p. 98).

Lukàcs's suggestion that Marx's totality perspective was closely bound up with Hegel's dialectical method takes us back to one of the aims of this paper, namely identifying a non-Hegelian dialectical method that even the most orthodox thinkers would probably rate as acceptable. In particular, a form of dialectical thinking that mainstream thinkers are likely to accept is the method of the "interpenetration of opposites", which is concerned with "reconciling contradictions" (see [39] Sowell, 1985, pp. 28-35) or highlighting a sudden change or reversal of circumstances which until then had been perceived as fixed and given ([40] Luporini, 1966, p. 155 and [41] 1974, p. IX). ${ }^{5}$

Using the phrase "unity of differences" to describe mutual relationships, in Capital Marx argued that "the independence of the individuals from each other has as its counterpart and supplement a system of all-round material dependence" ([43] pp. 140-03). And Trotsky, according to whom explaining dialectics was "the only way to begin the theoretical education of the Party" ([44] Trotsky, 1940a, p. 177), polemically wrote to Burnham: "Your errors are not accidental. You approach each question by isolating it, by splitting it away from its connection with other questions... You lack the dialectic method" ([45] Trotsky, 1940, p. 165). Lenin described dialectics as the most intriguing of all philosophical issues and a tool which reveals the reciprocal interaction of everything with everything else (see [46] Meyer, 1957, pp. 19-21). ${ }^{6}$

Viewed as the analysis of "interpenetrating opposites", dialectics helps expand

${ }^{5}$ In this connection, the great theorist of world systems, Immanuel Wallerstein, has argued ([42] 2006 , p. 14) that "the division of knowledge into distinct boxes-disciplines-is an obstacle, not an aid, to understanding the world".

${ }^{6}$ For a comparable view, see [47] Bernstein, 1899, p. 52. 
"our notion of anything to include, as aspects of what it is, both the process by which it has become that and the broader interactive context in which it is found" ([48] Ollman, 2003, p. 13) and makes us aware that in any dialectical interactions, whether mutual or between unequal poles, the "dominant determination runs from one pole to the other". Without this, Laibman argued ([49] 2007, p. 4), "the dialectic characterizes the mutual conditioning of the poles, their relational consistency, but does not reveal a dynamic movement in the system that they constitute" (see, also, [39] Sowell, 1985, pp. 28-33). In sum, dialectical thinking turns a spotlight on contrasts and contradictions within the dynamics of society (see, inter alia, [50] Labriola 1902). In other words, for a contradiction to qualify as dialectical it must express the essence of movement ([51] Lukàcs, 1956, p. $92^{7}$ and [53] and [54] Colletti, 1974 and 1980). Indeed, the latter has repeatedly emphasised that the contradictions that are highlighted must be material, not just logical.

The main effect of a totality-focused dialectical approach is to magnify the impact of causality on the context, in terms that its individual components will be perceived as different depending on the specific totality they are part of from time to time. The end result is a compound of effects which impact on the elements constituting the system ([55] Karsz, 1974, p. 131).

The importance of a simultaneous focus on the issue concerned and the surrounding totality was also underscored by Althusser. In Althusser's view, this was the only effective way to address and solve an issue dialectically, but he also claimed that this was only applicable to the method used by Marx. Hegel's, he argued, was antithetical to the non-contradiction principle and "completely dependent on the radical presupposition of a simple original unity which develops within itself by virtue of its negativity" and "only ever restores the original simplicity and unity in an ever more 'concrete' totality" throughout its development ([56] Althusser, 1965, p. 175).

From this, it follows that no one sharing Althusser's view of dialectics as totality-focused should use a form of dialectical thinking that can be re-interpreted as economic determinism (see [57] Sabine, 1953, p. 598). In Althusser's approach, therefore, economic determinism descends from the idea of a linear causal chain implying direct cause-effect relations, i.e. relations between a single paramount cause and the effects that passively flow from it. The economic base is the necessary and, in itself, sufficient cause, whereas the superstructure, stripped of its autonomy, becomes ineffectual and production relations are seen to be shaped directly by the prevailing technological standards. Hence, the idea of a predetermined course of things, materialism, gives rise to economic fatalism, i.e. determinism. On closer analysis, however, this is the conception connoting mechanistic materialism, rather than Marx's approach, and as this conception tends to obliterate the part played by superstructural factors, it is unable to account for the rise of existing forms of society and their different characteristics (see [55] ${ }^{7}$ In the opinion of Lefebvre ([52] 1968, p. 124), unless the purpose is stopping a process, contrasting one term with another is not enough to secure comprehension. Each opposition entails, i.e. dissimu-lates and reveals, a dialectical movement. 
Karst, 1974, pp. 120-124).

Althusser's idea that dialectics is antithetical to determinism is shared by Sowell ([39] see Sowell, 1985, pp. 30-31).

The paramount place of totality in Marx is the result of his particular view of history and dynamics, but Althusser specifies that "the structure of the whole must be conceived before any discussion of temporal sequence" (see [58] Althusser \& Balibar, 1965, p. 105).

The overriding importance of the totality perspective in Marxism calls to mind the typical approach of all the cultural movements of the structuralist family (in the natural, human and/or social sciences), whose prime criterion is the need to focus on each research object as an integral whole.

In sum, the idea of dialectics as a totality-focused analysis method goes to support the argument that Marx's method differs from mainstream scientific methods in many ways, but that none of the relevant differences are such as to nullify the scientific essence of Marxism. ${ }^{8}$

Galvanodella Volpe, one of the scholars who draw a clear-cut distinction between Marx's and Engels's respective methods, maintains that the dialectical method developed by Marx is both "scientific or analytical" and characterised by the so-called "concrete-abstract-concrete circle". More precisely, della Volpe describes Marx's method as moving from the concrete to the abstract and then back to the concrete and holds it to be compatible with the non-contradiction principle (see [62] della Volpe, 1964).As for me, I both deny that Marx's method shows the forward-backward movement described by Della Volpe and am rather inclined to agree with Gruppi 1962 ([63] p. 159) that the concrete-abstract-concrete model is much more restrictive than the totality-focused model and is likely to impoverish, if not altogether nullify, the dialectical approach.

\section{Dialectics as a Method and a System of Thought}

In 1958, Norberto Bobbio emphasised the distinction between two notions of di-

\footnotetext{
${ }^{8}$ The relevance of Marx's totality-focused approach seems to be particularly evident today, when economists "have explained away and have caused their users to turn a blind eye on the overall mechanisms of capitalism" (see [59] Becattini, 2009, p. 76).Even more so, the notion of "totality" is also crucial to Lacan's interpretation of Freud, who has taught that "everything" is stored within the unconscious. According to Lacan, Freud's most revolutionary achievement was to dethrone the Ego and place the source and origin of individual activity in the unconscious: the choices of a subject are not governed by his Ego, but by unconscious drives; and the whole process-let this be repeatedacts itself out within the unconscious, not the Ego. In Lacan's own words: “The ego is a function, the ego is a synthesis, a synthesis of functions, a function of synthesis. It is autonomous! That's a good one! It's the latest fetish introduced into the holy of holies of a practice that is legitimated by the superiority of the superiors" (see [60] Lacan, 1955, p. 203). There are no traces of this in the approa-ches of mainstream economists.

The link between Marx and Freud in this area is acknowledged by Althusser when he writes ([61] 1974, p. 29). "Since Copernicus we have known that the earth is not the 'centre' of the universe. Since Marx we have known that the human subject, the economic, political or philosophical Self, is not the centre of history; and even in opposition to the philosophers of the Enlightenment and to Hegel, that history has no 'centre', but a structure which has no necessary 'centre' except in ideological misrecognition. In turn, Freud has discovered for us that the real subject, the individual in his essence, has not the form of an ego centred on... 'consciousness"'.
} 
alectics. "Faced with two conflicting entities-he wrote-we may either opt for the 'compenetration-of-opposites' (or mutual-interaction) method or for a method founded on the 'negation of the negation'. When the former is adopted, both entities are kept firm and are assumed to mutually condition each other; when the latter is adopted, we assume that the first entity is cancelled by the other at a first stage and the second by the third at a subsequent stage" ([64] Bobbio, 1958, p. 347). Concerning these antithetical methods, Badaloni 1962 argued ([65] p. 110) that the former was the method of Marx the mature economist and scientist, while the latter was the method of the younger Marx.

Bobbio's argument is in line with the already mentioned distinction between Hegel's dialectic, which Sichirollo ([66] 1973, p. 149) describes as "the world as it appears in discourse", rather than a method, and the Marxist dialectical method, which I am prepared to accept and which does not rule out the noncontra-diction principle. ${ }^{9}$

For purposes of greater clarity, let ne re-emphasise that while Hegel expects us to accept the "union of opposites" as "a result of speculative thinking" without regard for the fact that it may appear "nonsensical to the understanding" (see ([22] Hegel, 1831, p. 14), Marx's dialectical approach, which I accept, is a method which explains dynamics and does not negate the validity of the noncontra-diction principle. Both Bobbio 1958 ([64] pp. 343-346) and Dal Pra 1972 ([23] pp. viii-x) are agreed that the latter approach was preferably used by Marx in his mature years.

An expert on Marx such as Roberto Fineschi 2007 ([68] p. 183) contends that Marx did accept "the self-driven movement of notions, i.e. the laws of dialectics laid down by Hegel", but that he rated them nothing but an effective method for describing things, not for materially creating them.

In fact, there is no denying that Marx used the distinctly Hegelian "negation of the negation".

According to Hudis 2000 [69], for instance, a case in point is Marx's proposition that capitalism cannot be superseded by simply suppressing private property. In Marx's own words, the abolition of private property was just the first negation and, as such, it required a second negation, the negation of capital, as the negation of the negation. A well-known statement by Hegel runs: "care must be taken to distinguish between the first negation as negation in general, and the second negation, the negation of the negation; the latter is concrete, absolute negativity, just as the former on the contrary is only abstract negativity" (see [22] Hegel, 1831, p. 134). Similarly, at the end of his third 1844 Manuscript, Marx wrote: "communism is the position as the negation of the negation, and is hence the actual phase necessary for the next stage of historical development in the next stage of historical development in the process of human emancipation and rehabilitation" ([70] Marx, 1844, p. 126). An additional relevant statement from

${ }^{9}$ Tosel 2007 (671] p. 299) has argued that Hegel's rejection of the non-contradiction principle can be traced to his wish to have the logical fall in with what is real (see, also, Popper), while Marxists may well accept the principle of non-contradiction since they do not attach equal importance to this equation. 
Capital runs: "The capitalist mode of appropriation, which springs from the capitalist mode of production, produces capitalist private property. This is the first negation of individual private property, as founded on the labour of its proprietor. But capitalist production begets, with the inexorability of a natural process, its own negation. This is the negation of the negation" ([43] Marx, 1867, p. 929). In the Postscript to the second edition of Volume I of Capital we also read ([43] Marx, 1867, p. 103): "the mystification which the dialectic suffers in Hegel's hand by no means prevents him from being the first to present its general forms of motion in a comprehensive and conscious manner" ${ }^{10}$ In Antidühring (which Marx read through and unconditionally endorsed), Engels expatiates on the reasons why he holds that Marx's use of the negation of the negation has nothing in common with Hegel's dialectic (see [72] Engels, 1878, pp. 142-143).

Accordingly, it is hardly possible to share the widely held view that it was Engels, rather than Marx, who continued to use Hegelian dialectics (see, for instance, [73] Cingoli, 2005, p. 129).

However, in the light of this line of reasoning and the opinions of authors suggesting different interpretations of Marx it is worth re-emphasising that our my claim that Marx's dialectical method is compatible with formal logic is prevailingly supported by the fact that some of these interpretations, with which I concur, are compatible with science, rather than by a careful textual analysis of Marx's own writings.

\section{The Notion of History in Marx}

Marx describes history as a process, governed by laws, which unfolds as an uninterrupted chain of changes in the structure of social interrelations (see [74] Fleitscher, 1969, p. 41). In an early work such as The German Ideology ([75] Marx \& Engels, 1845-46, p. 27) he and Engels wrote that "History is nothing but the succession of the separate generations, each of which exploits the materials, the capital funds, the productive forces handed down to it by all preceding generations, and thus, on the one hand, continues the traditional activity with a completely changed activity". Further on, they added ([75] p. 59) that history is "the history of the evolving productive forces taken over by each new generation, and is, therefore, the history of the development of the forces of the individuals themselves". To Marx's thinking, "production forces evolve from within on an impulse which is inherent in them and impress their imprint on the institutions of a society and its ideologies. Both in Marx and in Hegel, the strongest impulse was an expansive metaphysical factor shaping reality" ([57] Sabine, 1953, p. 603), namely the factors of production.

Hence, even an early work such as The German Ideology (see [75] p. 53) is evidence that Marx's approach, historical materialism, is mainly aimed to "expound the real process of production, starting out from the material production of life itself, and to comprehend the form of intercourse connected with this and

${ }^{10}$ In contrast, both Adorno and Habermas maintain that Marx's dialectic does not depart from Hegel's and is at odds with formal logic (see [71] Habermas, 1963, chap. iv). 
created by this mode of production (i.e. civil society in its various stages), as the basis of all history; and to show it in its action as state, to explain all the different theoretical products and forms of consciousness, religion, philosophy, ethics, etc., and trace their origin and growth from that basis; by which means, of course, the whole thing can be depicted in its totality (and therefore, too, the reciprocal action of these various sides on one another)".

It is a well-known fact that right to his maturity Marx held on to the belief that the true foundation of the historical process was material production. In his own words: "My inquiry led me to the conclusion that neither legal relations nor political forms could be comprehended whether by themselves or on the basis of the so-called general development of the human mind, but that on the contrary they originated in the material conditions of life, the totality of which Hegel, following the example of English and French thinkers of the eighteenth century, embraces within the term 'civil society"' ([76] Marx, 1859, p. 746).

Praising the sheer novelty of Marx's materialist approach to history, Althusser emphasised that the refusal to posit the essence of man as the basis of history enabled Marx to accomplish a radical theoretical revolution, i.e. to reject the "idealism of the essence" and replace "the old couple individuals/human essence in the theory of history by new concepts (forces of production, relations of pro-duction, etc.)" ([56] Althusser, 1965, p. 204).

The teleological overtones that were still perceived in the Economic-Philosophical Manuscripts of 1944 are absent from the conception of history of the mature Marx, who rejected the extension of Darwinism to the social sciences. ${ }^{11}$

In Althusser's view, thanks to the discovery of production modes, the way they arise, grow and die out, Marx made a major contribution to the advancement of scientific knowledge and laid the foundations for a theoretical edifice which is at the basis of all the sciences falling within the domain of history in the broadest possible meaning of this word ([56] Althusser, 1969 and [80] Althusser, 1995, p. 23). In this connection, Therborn 1971 ([77] p. 104) has argued that Althusser holds the notion of modes of production to be the very cornerstone of historical materialism.

In actual fact, dissenting from Althusser I have to remark that Marx did not deny the importance of the subject, i.e. humankind, in history. "Men-he wrote ([78] Marx, 1852, p. 487)-make their own history". In the opinion of Marx, theory has to be combined with practice, but for this to happen "the emergence of consciousness must become the decisive step which the historical process must take towards its proper end-an end constituted by the wills of men but neither dependent on human whim nor the product of human invention" ([79] Lukàcs, 1923, p. 3). ${ }^{12}$

\footnotetext{
${ }^{11}$ Among Marxists, let me mention especially Kautsky, whose opinions on links between Darwin and socialism changed with the passing of years. At the time he was editing the NeueZeit, he used to emphasise such links, but starting from 1890 ever more often denied them.

${ }^{12}$ Engels, for his part, wrote: "Men make their own history, but in a given, conditioning milieu, upon the basis of actual relations" ([81] Engels, 1894, p. 108).
} 
The laws by which history is governed arise in connection with the fact that history is the record of the way productive forces evolve. Moreover-and this is what I wish to emphasise-all such movement as is observed within the historical process is sparked off by the contradictions within modes of production.

\section{Identifying the Basic Contradiction of Capitalism}

At this point, it is time to ask ourselves which of the contradictions of capitalism is to be classed as the severest of all.

From the vantage point of a Marxist, the severest contradiction of capitalism is the antithesis between capital and labour, i.e. two classes pursuing antithetical interests. This contradiction is held to be unbearable because it originates from the fact that individuals are controlled by capital, that is to say a compound of inanimate things, and not vice versa, as would be in the nature of things. As will be clarified further on, with the passing of time this contradiction tends to be superseded as a result of the laws of motion in capitalism. Although I am aware that the analysis of this well-known contradiction in a Marxist key may appear redundant, from my perspective a few clarifications are necessary. ${ }^{13}$

Consider a system of cooperatives of the LMF type as defined by Vanek 1971a and 1971b ([82] and [83]). As is well known, LMFs are worker-run firms which exclusively use loan capital. What would become of the contradiction between capital and labour-one may ask-in a society which has adopted such a system in place of capitalism? As is well known, a capitalistic enterprise can be defined one where capital hires labour, runs the operations of the enterprise in its exclusive interests, pays workers fixed incomes (wages and salaries) and appro-priates the surplus. In contrast, a Vanek-type LMF is a firm whose workers borrow capital, pay it a fixed income rate (interest), run the firm's business in their own interests and cash the surplus. Hence, the transition from capitalism to a system of Vanek-type firms reverses the customary capital-labour relation by stripping capitalists of their corporate sovereign powers and vesting such powers in workers along with the right to decide how production shall be managed-as is in the nature of things.

Establishing if, and what manner, the reversal of the capital-labour relation might help supersede this contradiction is no trivial issue. Marx's approach to the contradictions of capitalism is basically dialectical and dialectics, as is well known, is a method which entails the assumption that reality evolves at the same pace that its inherent contradictions are solved and superseded. Inasmuch as this is true, what it the true import of the claim that a reversed capital-labour relation solves one of the contradictions of capitalism?

Presumably, it would not solve the contrast between capital and labour since

\footnotetext{
${ }^{13}$ It has long been customary to describe political economy as a scientific discipline concerned with demonstrating that capital and labour are not in conflict. A nineteenth-century economist once wrote that thanks to the effective circulation of the teachings of economic science right across the nation British workers had ceased looking on capital as the enemy of labour, has stopped breaking machinery and had come to bear the sufferings associated with the American crisis with exemplary resignation (cited in [81] Favilli, 2001, p. 383).
} 
this is basically the effect of an income distribution pattern determining that the share of the aggregate national income appropriated by one class increases in proportion to the decrease of the share assigned to the other. Although the resulting conflict of interests would be somewhat cooled off by this revolution, it would nevertheless outlast it since capitalists would keep cashing interest on their loans even after the establishment of a worker-controlled firm system. This prompts the conclusion that the capital-labour contradiction and the conflict of interests mentioned above are two different things. ${ }^{14}$

In contrast, the reversed capital-labour relation does solve the capital-labour contradiction because the higher incomes and qualifications that workers are sure to acquire with the passing of time will ultimately enable this class to wrest itself free from the capitalistic yoke and take over the management of firms. Democratic firm management marks a major stride forward in the direction of freedom and Marxism in its truly Marxian version has a unilinear view of history because it assumes that, albeit by the most tortuous of paths, history progresses towards the acquisition of ever greater freedom. As a result, there are reasons to think that the development of productive forces will enable workers to free themselves from their subjection and to change the prevailing production mode in such a way as to solve the contradiction resulting from the subjection of humankind to the laws of capital, its control by "things" and lack of freedom. ${ }^{15}$

In other words, in a world shaped by the reversed capital-labour relation the capital-labour contradiction typical of capitalism will be superseded since the laws of motion of capitalism ensure that, thanks to such reversal, workers will be in a position to appropriate the surplus generated by production. In other words, this reversal will create the assumptions for the attainment of the true goal of economic development: enabling humankind to exercise an ever more effective control over the environment.

\section{The Fundamental Contradiction of Capitalism According to Orthodox Marxists}

Neither Engels nor orthodox Marxists think of the capital-labour confrontation as the basic contradiction of capitalism. In orthodox Marxist terms, the basic contradiction originates from a mismatch between the socialised character of production in large-size industrial concerns (where hundreds and even thousands of workers see to their jobs side-by-side) and the private character of appropriation (the very underpinning of privately-owned production means) (see, for example, [85] Tsuru, 1969, p. 364-365). And according to Engels (and other Marxists),

\footnotetext{
${ }^{14}$ Hence, we cannot agree with Settembrini that "in a genuinely socialist regime the antithesis between the working class and the ruling class would be a contradiction in terms" (see [95] Settembrini 1975, p. 35).

${ }^{15}$ It has long been customary to describe political economy as a scientific discipline concerned with demonstrating that capital and labour are not in conflict. A nineteenth-century economist once wrote that thanks to the effective circulation of the teachings of economic science right across 81 nation British workers had ceased looking on capital as the enemy of labour, has stopped breaking machinery and had come to bear the sufferings associated with the American crisis with exemplary resignation (cited in [92] 84Favilli, 2001, p. 383).
} 
this contradiction sparks off an additional one, namely the contrast between socialised production and capitalistic appropriation that Engels explained as an antagonism between the organization of production in the individual workshop and the anarchy of production in the society as a whole.

To some degree, Engels's view is supported by the reflection that the transition from capitalistic to democratic firm management will solve both these contradictions at one stroke. As is well known, the aim of socialism is to eradicate the current economic model founded on individualism and private enterprise, replace it with a collaborative socialised model and, hence, solve the contrast between the collective nature of production activity and the private nature of distribution. And as a worker-controlled firm system vests decision powers in matters of production and distribution in collective bodies such as workers' councils, it is possible to conclude that the progress from capitalism to self-management will not only help supersede the capital-labour contradiction in the manner explained above, but effectively solve the contrast between socialised production and individualistic distribution.

Although these two contradictions are closely linked to each other, they are far from identical. The capital-labour confrontation reflects a class conflict, whereas the contrast between socialised production and private appropriation is generated by antithetical aspects of economic activity.

In support of this distinction it is possible to argue that the former, unlike the latter, is grounded in a conflict between economics and law (see [86] Struve, 1899, p. 120-121).

At this point, it is worth discussing an additional serious contradiction that Marx assumed to arise in connection with the fact that the world is "upside down", i.e. with an organisational model which runs counter to the natural order of things determining that the world should be "standing upright". This idea was first discussed in such an early work as the Contribution to the Critique of Hegel's Philosophy of Right, whose Introduction includes the following statement: "This state and this society produce religion, which is an inverted consciousness of the world, because they are an inverted world. Religion is the general theory of this world... the sigh of the oppressed creature, the heart of a heartless world, and the soul of a soulless condition" ([87] Marx, 1843, p. 5758).

His conclusion is that "the criticism of religion ends with the teaching that man is the highest essence for man-hence, with the categoric imperative to overthrow all relations in which man is a debased, enslaved, abandoned, despi-cable being" ([87] Marx, 1843, p. 65).

Fineschi2005 ([88] p. 111) notes close links between Marx's idea of an inverse relation between capital and labour in capitalism and his theory of alienation, while Colletti sees Marx's notion of capitalism as interconnected with his vision of a reversed world and the theories of alienation and fetishism. These processeshe remarks ([89] Colletti, 1979, p. 70) - "are structured in the same way as is the subject-predicate inversion", because it is the realty of the capitalistic world that 
is turned upside down.

The reason why Marx's mature works describe the world as turned upside down is that market mechanisms, while preventing man from exercising control over things (i.e. labour from using means of production), create the assumptions for things to control man and capital to dictate the laws to which labour must conform. In volume three of Capital Marx wrote ([90] p. 311): "In competition, therefore, everything appears upside down. The finished configuration of economic relations, as these are visible on the surface, in their actual existence, and therefore also in the notions with which the bearers and agents of these relations seek to gain an understanding of them, is very different from the configuration of their inner core, which is essential but concealed, and the concept corresponding to it. It is in fact the very reverse and antithesis of this".

As this suggests that the takeover of firms by workers would reverse the capital-labour relation and put the world back into kilter, ${ }^{16}$ it is to be assumed that Marx thought of the capital-labour opposition and the view of the world as upside-down as strictly interconnected issues. In addition to this, our line of reasoning suggests that the capital-labour opposition is also associated with the contrast between appearance and reality which is discussed in the theory of commodities exchange but would not be cancelled despite the reversal of the relation between capital and labour.

\section{Conclusion}

The distinction between socialism and communism must be accepted by any Marxist wishing to come to terms with globalisation. And as this distinction was first made by Lenin, it is to Lenin, rather than Marx or Engels that he will have to turn for a correct appreciation of the nature of socialism. After his experiments with wartime communism and the Nep, shortly before his death Lenin wrote a seldom-quoted article in which he spelt out that "cooperation is socialism" ([92] Lenin, 1923, p. 1801-1802). However, if socialism is a system in which cooperative firms are to operate in the market (though, admittedly, under a measure of State control), any Marxist intending to flesh out a socialist political economy must stop thinking of socialism as a non-market economy and use a method of analysis which is not at odds with mainstream economic science. Specifically, he will have to accept the non-contradiction principle and, consequently, reject $\mathrm{He}$ gelian dialectic thinking.

Inasmuch as it is true that a system of cooperative firms operating in markets is a socialist system, it is impossible to continue holding the traditional Marxist view that the key contradiction of capitalism is the contrast between socialised production activity and private appropriation since such a view will quite naturally lead to the conclusion that socialism is a centrally planned economy. And from this, it clearly follows that the basic contradiction of capitalism must necessarily be the confrontation between capital and labour.

${ }^{16}$ Colletti dissents on this point (see [89] Colletti 1970, pp. 311-314). 


\section{References}

[1] Hodgson, G.M. (1999) Economics and Utopia. Routledge, London.

[2] Chattopadhyay, P. (2010) The Myth of Twentieth-Century Socialism and the Continuing Relevance of Karl Marx. Socialism and Democracy, 24.

[3] Jossa, B. (2012) Cooperative Firms as a New Mode of Production. Review of Political Economy, 24, 399-416. https://doi.org/10.1080/09538259.2012.701915

[4] Jossa, B. (2012) A System of Self-Managed Firms as a New Perspective on Marxism. Cambridge Journal of Economics, 36, 821-841. https://doi.org/10.1093/cje/bes012

[5] Jossa, B. (2014) A System of Cooperative Firms as a New Mode of Production. Routledge, London.

[6] Rigi, J. (2013) Peer Production and Marxian Communism: Contours of a New Emerging Mode of Production. Capital \& Class, 37.

[7] Benkler, Y. (2006) The Wealth of Networks: How Social Production Transforms Markets and Freedom. Yale UP, New Haven.

[8] Kleiner, D. (2010) The Telecommunist Manifesto. Institute of Network Cultures, Amsterdam.

[9] Marx, K. (1858) Letter to Engels. Ital. Trans. In: Marx, K. and Engels, F., Eds., Carteggio.

[10] Bhaskar, R. (1991) “Dialectics” Entry. In: Bottomore, T.B., Ed., A Dictionary of Marxist Thought, 2nd Edition, Blackwell, Oxford.

[11] Schumpeter, J.A. (1954) Storiadell'analisieconomica. Ital. Trans., Einaudi Turin, 1959.

[12] Rosenthal, J. (1998) The Myth of Dialectics: Reinterpreting the Marx-Hegel Relation. Macmillan, London. https://doi.org/10.1057/9780230371842

[13] Bidet, J. (1998) Que faire du Capital? Presses Universitaires de France, Paris.

[14] Meyer, T. (1994) Analytical Marxism. Vol. 1. Sage Publications, London.

[15] Rosdolsky, R. (1955) Genesi e strutturadelCapitale di Marx. Ital. Trans., Laterza Bari, 1971.

[16] Bernier, B. (1974) Conrad Schmidt e l'inizio della letteratura economica "marxista". In: Istituto Giangiacomo Feltrinelli, Ed., Storia del marxismo contemporaneo, Feltrinelli, Milan.

[17] Gentile, G. (1974) La filosofia di Marx. Sansoni, Florence.

[18] Rockmore, T. (2005) Lukàcs tra Marx e il marxismo. In: Fineschi, R., Ed., Karl Marx: Rivisitazioni e prospettive, Mimesis, Milan.

[19] Croce, B. (1899) Materialismo storico ed economia marxista. Laterza, Bari, 1968.

[20] Hyppolite, J. (1969) Lo <scientifico $>$ e l'<ideologico $>$ in una prospettiva marxista. In: AA. VV., Ed., Marx vivo, Mondadori, Milan.

[21] Garaudy, R. (1969) Il concetto di struttura in Marx e le concezioni alienate della struttura. In: AA. VV., Ed., Marx vivo, Mondadori, Milan.

[22] Hegel, G.W.F. (1831) Scienzadellalogica. 2nd Edition, Ital. Trans., Laterza Bari, 1974.

[23] DalPra, M. (1972) La dialettica in Marx. Laterza, Bari.

[24] Bidet, J. (2001) New Interpretations of Capital. In: Bidet, J. and Kouvelakis, S., Eds., Critical Companion to Contemporary Marxism, Brill, Leiden and Boston, 2008.

[25] Kincaid, J. (2001) The New Dialectic. In: Bidet, J. and Kouvelakis, S., Eds., Critical Companion to Contemporary Marxism, Brill, Leiden and Boston, 2008.

[26] Fine, B. (2001) The Marx-Hegel Relationship: Revisionist Interpretations. Capital \& Class, Special Issue, No. 75. https://doi.org/10.1177/030981680107500106 
[27] Bhaskar, R. (1993) Dialectic: The Pulse of Freedom. Verso, London.

[28] Geary, R.J. (1974) Difesa e deformazione del marxismo. In: Kautsky, in Istituto Giangiacomo Feltrinelli, Storia del marxismo contemporaneo, Feltrinelli, Milan.

[29] Sylos Labini, P. (2006) Perché gli economisti devono fare i conti con Marx. In: Jossa, B. and Lunghini, G., Eds., Marxismo oggi, Il Ponte Editore, Florence.

[30] Marx, K. (1864) Inaugural Address of the Working Men's International Association. In: Marx, K. and Engels, F., Eds., Collected Works, Vol. 7, Lawrence and Wishart, London.

[31] Marx, K. and Engels, F. (1848) Manifesto of the Communist Party. In: Marx, K. and Engels, F., Eds., Collected Works, Vol. 6, Lawrence and Wishart, London.

[32] Screpanti, E. (2007) Comunismo libertario. Manifestolibri, Rome. https://doi.org/10.1057/9780230596474

[33] Lichtheim, G. (1965) Marxism; an Historical and Critical Study. F.A. Praeger, New York."

[34] Lukàcs, G. (1968) Scritti politici giovanili, 1919-1928. Laterza, Bari.

[35] Rovatti, P.A. (1973) Critica e scientificità in Marx. Feltrinelli, Milan.

[36] Rusconi, G.E. (1968) La teoria critica della società. Il Mulino, Bologna.

[37] Negt, O. (1979) L’ultimo Engels. In AA. VV., Ed., Storia del marxismo, Vol. 2, Einaudi, Turin.

[38] Balibar, E. (1993) La filosofia di Marx. Ital. Trans., manifestolibri, Rome, 1994.

[39] Sowell, T. (1985) Marxism; Philosophy and Economics. Quill William Morris, New York.

[40] Luporini, C. (1966) Realtà e storicità: Economia e dialettica nel marxismo.

[41] Luporini, C. (1974) Dialettica e materialismo. Editori Riuniti, Rome.

[42] Wallerstein, I. (2006) Comprendere il mondo. Asterioseditore, Trieste.

[43] Marx, K. (1867) Capital. Vol. 1, Penguin Books, Harmondsworth, 1986.

[44] Trotsky, L. (1940) Letterto James P. Cannon. In: Trotsky, L., Ed., In difesa del marxismo, Samonà e Savelli, Rome.

[45] Trotsky, L. (1940) Open letter to ComradBurnham. In: Trotsky, L., Ed., 1969, In difesa del marxismo, Samonà e Savelli, Rome.

[46] Meyer, A.G. (1957) IlLeninismo. Ital. Trans., Edizioni di Comunità, Milan, 1965. https://doi.org/10.4159/harvard.9780674186637

[47] Bernstein, E. (1899) Socialismo e socialdemocrazia. Ital. Trans., Laterza, Bari, 1969.

[48] Ollman, B. (2003) Dance of the Dialectic; Steps in Marx's Method. University of Illinois Press, Chicago.

[49] Laibman, D. (2007) Deep History. State of New York Press, New York.

[50] Labriola, A. (1902) Discorrendo di socialismo e di filosofia. Edizioni Millennium, Bologna, 2006.

[51] Lukàcs, G. (1956) La lotta tra progresso e reazione nella cultura d'oggi. In: Lukàcs, G., Ed., 1968, Marxismo e politica culturale, Einaudi, Turin.

[52] Lefebvre, H. (1968) Bilancio di un secolo e di due mezzi secoli (1867-1917-1967). In: AA. VV., Ed., Cent'anni dopo il Capitale, Ital. transl., Samonà e Savelli, Rome.

[53] Colletti, L. (1974) Intervista politico-filosofica. Laterza, Bari.

[54] Colletti, L. (1980) Tramonto dell'ideologia. Laterza, Bari.

[55] Karst, S. (1974) Teoria e politica: Louis Althusser. Ital. transl., Dedalo libri, Bari, 1976. 
[56] Althusser, L. (1965) Per Marx. Ital. transl., Editori Riuniti, Rome, 1969.

[57] Sabine, G.H. (1937) Storia del pensiero politico. Ital. transl., Edizioni di Comunità, Milan, 1962.

[58] Althusser, L. and Balibar, E. (1965) Leggere Il Capitale. Ital. transl., Feltrinelli, Milan, 1968.

[59] Becattini, G. (2009) Il mea culpa degli economisti, in Il Ponte, Ybk LXV, No. 10.

[60] Lacan, J. (1955) La cosa freudiana. In: Lacan, J., Ed., 1972, La cosa freudiana e altri scritti, Einaudi, Turin.

[61] Althusser, L. (1974) Elements of Self-Criticism. In: Althusser, L., Ed., 1976, Essays in Self-criticism, New Left Books, Londra.

[62] Della Volpe, G. (1964) Rousseau e Marx. 4th Edition, Editori Riuniti, Rome.

[63] Gruppi, L. (1962) Contro l'impoverimento della dialettica marxista. In: Cassano, F., Ed., 1973, Marxismo e filosofia in Italia, De Donato, Bari.

[64] Bobbio, N. (1958) La dialettica in Marx. Rivista di filosofia, 49, 334-354.

[65] Badaloni, N. (1962) Marxismo come storicismo. Feltrinelli, Milan.

[66] Sichirollo, L. (1973) Dialettica. ISEDI, Milan.

[67] Tosel, A. (2007) Teleologia, dialettica, biforcazione. Quale dialettica oggi? In: Burgio, A., Ed., Dialettica; tradizioni, problemi sviluppi, Quodlibet Studio, Macerata.

[68] Fineschi, R. (2007) Attualità e praticabilità di una teoria dialettica del "Capitale" (ovvero: Marx è un ferro vecchio)? In: Burgio, A., Ed., Dialettica; tradizioni, problemi sviluppi, Quodlibet Studio, Macerata.

[69] Hudis, P. (2000) The Dialectial Structure of Marx's Concept of 'Revolution in Permanence. In: Capital \& Class, Spring, Berlin, No. 70.

[70] Marx, K. (1844) Manoscritti economico-filosofici del 1844. Einaudi, Turin, 1968.

[71] Habermas, J. (1963) Teoria e prassi nella società tecnologica. Ital. transl., Laterza, Bari, 1969.

[72] Engels, F. (1878) Anti-Dühring. In: Marx, K. and Engels, F., Eds., Collected Works, Vol. 25.

[73] Cingoli, M. (2005) Marx e il materialismo. In: Musto, M., Ed., Sulle tracce di un fantasma, manifestolibri, Rome.

[74] Fleischer, H. (1969) Marxismo e storia. Il Mulino, Bologna.

[75] Marx, K. and Engels, F. (1845-1846) L'ideologia tedesca. Ital. transl., 3rd Edition, Editori Riuniti, Rome.

[76] Marx, K. (1859) Contribution to a Critique of Political Economy. Ital. transl., Editori Riuniti, Rome, 1969.

[77] Therborn, G. (1971) Critica e rivoluztione: La scuola di Francoforte. Ital. transl., Laterza, Bari, 1972.

[78] Marx, K. (1852) Il 18 brumaio di Napoleone Bonaparte. In: Marx, K. and Engels, F., Eds., 1966, Opere scelte, Editori Riuniti, Rome.

[79] Lukàcs, G. (1923) Storia e coscienza di classe. Ital. transl., SugarcoEdizioni, Milan.

[80] Engels, F. (1894) Prefazione al terzo volume del Capitale. In: Marx, K., Ed., 1894, II Capitale, Vol. 3, Editori Riuniti, Rome, 1965.

[81] Favilli, P. (2001) Socialismo e marginalismo. La "battaglia delle idee": Una lettura. In: Guidi, M.E.L. and Michelini L., Eds., 2001, Socialismo e marginalismo nell Italia liberale, 1870-1925, Feltrinelli, Milan.

[82] Vanek, J. (1971) Some Fundamental Considerations on Financing and the Form of 
Ownership under Labor Management. In: Vanek, J., Ed., 1977, The Labor Managed Economy: Essays by J. Vanek, Cornell University Press, Ithaca.

[83] Vanek, J. (1971) The Basic Theory of Financing of Participatory Firms. In: Vanek, J., 1977, The Labor Managed Economy: Essays by J. Vanek, Cornell University Press, Ithaca.

[84] Settembrini, D. (1975) Il labirinto marxista. Rizzoli, Milan.

[85] Tsuru, S. (1969) Marx e l'analisi del capitalismo. Un nuovo studio della contraddizione fondamentale? In: AA. VV., Ed., Marx vivo, Mondadori, Milan.

[86] Struve, P. (1899) La théoriemarxienne de l'évolution sociale. In: Cahiers de P Institut de science économiqueappliquée, No. 129, 1962.

[87] Marx, K. (1843) Critica della filosofia hegeliana del diritto pubblico. In: Marx, K. and Engels, F., Eds., 1966, Opere scelte, Editori Riuniti, Rome.

[88] Fineschi, R. (2005) Teoria della storia e alienazione in Marx. In: Fineschi, R., Ed., Karl Marx. Rivisitazioni e prospettive, Mimesis, Milan.

[89] Colletti, L. (1979) Tra marxismo e no. Laterza, Bari.

[90] Marx, K. (1894) Il Capitale. Vol. 3, Editori Riuniti, Rome, 1965.

[91] Colletti, L. (1970) Ideologia e società. Laterza, Bari.

[92] Lenin, V.I. (1923) Sulla cooperazione. In: Lenin, V.I., Ed., 1965, Opere scelte, Editori Riuniti, Rome.

Submit or recommend next manuscript to OALib Journal and we will provide best service for you:

- Publication frequency: Monthly

- 9 subject areas of science, technology and medicine

- Fair and rigorous peer-review system

- Fast publication process

- Article promotion in various social networking sites (LinkedIn, Facebook, Twitter, etc.)

- Maximum dissemination of your research work

Submit Your Paper Online: Click Here to Submit

Or Contact service@oalib.com 